\title{
CAPITAL REQUIREMENTS IN UNITED STATES \\ CORPORATION LAW
}

\section{By Richard A. Booth}

This article focuses on corporation law in the United States as it relates to capital contributions and capital maintenance. In other words, this article addresses the provisions of corporation law relating to (1) the obligation of investors to contribute to the corporation a specified amount of capital and (2) the obligation of the corporation to maintain a specified amount of capital (and not to pay it back to the stockholders in the form of dividends or payments to repurchase or redeem shares).Traditionally, the amount of capital that must be contributed to and maintained by a corporation is called the legal capital of the corporation. ${ }^{1}$ Thus, I refer here to the rules relating to these matters as legal capital rules.

It is important to recognize that corporation law in the United States is state law. There is no general federal corporation law, although there are a few federally chartered corporations. And there is no federal common law relating to corporations.

The legal capital rules vary widely from state to state. Indeed, it is arguable that the legal capital rules differ more from one state to the next than any other feature of corporation law. Accordingly, it is fair to say that there is little agreement among lawmakers as to the rationale for and wisdom of such rules. It is also fair to say, however, that few American legal scholars perceive that these rules are important. Few bother to focus on them in their law school classes, and few publish any significant scholarship on the subject. On the other hand, the subject is quite interesting from an historical perspective and offers important insights into how corporation law evolved in the United States.

The legal capital rules such as they are apply only to corporations. There are no legal capital rules applicable to other forms of organization such as partnerships and limited liability companies (although there are few very general default rules about capital accounts in connections with these forms of organization).

\footnotetext{
${ }^{1}$ See generally Bayless Manning \& James J. Hanks, Jr., LEGAL CAPITAL (1990) (hereinafter Manning \& Hanks).
} 
This article is divided into three parts. First, I outline the history and evolution of legal capital rules in the United States. Although these rules have been de-emphasized in recent years, particularly in the Model Business Corporation Act (MBCA) and the states that follow it, the legal capital rules remain on the books of numerous states and continue to be litigated from time to time. Second, I describe and analyze the legal capital rules currently in force in the major commercial jurisdictions, including Delaware, New York, and California. In addition, I will describe the rules as currently set forth in the MBCA. Again, there are remarkable variations in the rules from state to state. For example, as I discuss further below, California requires its corporations to maintain a balance sheet conforming to generally accepted accounting principals (GAAP) and limits the payment of dividends to either retained earnings or assets in excess of 125 percent of liabilities. Delaware, on the other hand, permits dividends without reference to a formal balance sheet. For example, under Delaware law a corporation may pay a dividend to the extent that going concern value exceeds long term debt and stated capital. Third, I describe the various rules that have taken the place of the legal capital rules in the United States. These include federal securities law, fraudulent transfer statutes, bulk sale statutes, veil piercing doctrine, successor liability doctrine, fiduciary duty doctrine relating to corporations operating on the edge of insolvency, and a variety of corporation statutes relating to particular transactions such as sales of assets and dissolution. (I do not address any industry-specific capital rules such as those relating to banks, brokers, or insurance companies.)

\section{HISTORY \& EVOLUTION OF LEGAL CAPITAL RULES}

The best way to understand corporation capital requirements in the United States is to consider the matter from an historical perspective. Prior to 1811, one could not form a corporation except by legislative act. In that year, New York enacted legislation permitting the formation of manufacturing corporations without specific legislative action. ${ }^{2}$ In 1845 , Louisiana adopted a new constitution that prohibited the legislative charter of corporations, apparently as a result of the perception that legislative charters smacked of privilege and elitism. ${ }^{3}$ Whatever the reason, it presumably became necessary to set up more

\footnotetext{
${ }^{2}$ See William T. Allen \& Reinier Kraakman, COMMENTARIES AND CASES ON THE LAW OF CORPORATIONS 85 (2003).

${ }^{3}$ Id. at $85-86$.
} 
or less standard rules relating to the amount of capital that must be contributed to a corporation in order for it to commence doing business. In the days of legislative charters, such matters could be individually negotiated according to the nature of the business. With incorporation under a general act, one needs rules.

In 1875, New Jersey enacted the first general corporation statute. That statute was revised in 1896, among other things, to permit one corporation to hold the shares of another and thus to permit the formation of so-called trusts such as Standard Oil. This statute was copied virtually verbatim by Delaware, where it was enacted in 1899. In 1913, under the leadership of Governor Woodrow Wilson, New Jersey eliminated several of the more liberal provisions of its corporation law, leaving Delaware as a more attractive place to incorporate, a position that it has maintained since that time. ${ }^{4}$

It is widely believed that the various states compete with each other to attract corporations. ${ }^{5}$ Although such competition does not appear to be a problem in other areas of the law, it is perhaps understandable that corporation law is different in that the corporations of one state are essentially free to operate in all states. Thus, many observers have suggested that the dilution of substantive rules such as those relating to legal capital may be attributable to destructive competition and the so-called race to the bottom in corporation law as each state competes to attract corporations by eliminating restrictions on their activities. Nevertheless, it is important not to jump to conclusions about the temptation of states to compete with each other. Indeed, several studies indicate that stock price tends to be higher for Delaware corporations than for corporations of other states, which suggests that stockholders (at least) may view the supposedly lax Delaware rules as better than those of other states. ${ }^{6}$ There is no reason to think that the states would not compete with each to offer the best possible legal product. Thus, although it may be tempting to assume that the demise of the legal capital rules is an example of increasing laxity in corporation law, it may also be the case that such rules proved to be inefficient and that other more efficient rules have evolved.

\footnotetext{
${ }^{4}$ See Mark J. Roe, Delaware's Competition, 117 Harv. L. Rev. 588 (2003).

${ }^{5}$ See id.

${ }^{6}$ See id.
} 
In any event, after the advent of free incorporation, state law required (1) that the charter of a corporation to be formed specify some minimum amount of capital for which subscriptions must be obtained and (2) that some specified portion of this amount in fact be paid before the corporation could legally commence doing business. ${ }^{7}$ Many of these provisions were included in state constitutions. Many of these statutes remained in force through the 1920 s and a few persisted until later particularly in more heavily regulated businesses. Presumably, state corporation commissioners reviewed the proposed amounts in much the same fashion as they would later review the merits of a securities offering. Presumably, these requirements were seen as the quid pro quo for limited liability. In other words, they were likely seen as a way to protect creditors who could not pursue their claims against the assets of individual stockholders if a business failed as they would be able to do against partners in an ordinary partnership. ${ }^{8}$ Nevertheless, it is not clear that the rules relating to par value and watered stock were intended to protect creditors. Rather, they may have been intended to assure equal treatment among subscribing stockholders, a function that was largely supplanted by the federal Securities Act of 1933.

In addition, most states placed limits on the maximum amount of capital that a corporation could raise from the sale of stock. ${ }^{9}$ In many cases, these limitations varied according to the nature of the business. New York abolished such limitations in 1890, but they persisted in several states into the 1920 s and beyond. ${ }^{10}$ Limits on the maximum amount of capital that a corporation might raise were undoubtedly the vestige of popular suspicion about the mystical idea that a corporation could have the legal status of a person and possibly even the older worry that corporations were an arm of the state. In any event, state corporation statutes combined provisions that were designed both to assure that a corporation raised sufficient capital for its purposes and to prevent the amassing of too much capital (and presumably power). The fact that corporation law sought to

\footnotetext{
${ }^{7}$ See Nixon v. Nixon, 196 Ga. 148; 26 S.E.2d 711; 1943 Ga. LEXIS 355 (citing statute providing that persons who organize a company and transact business in its name, before the minimum capital stock has been subscribed for, are liable to creditors to make good the minimum capital stock with interest).

${ }^{8}$ It is not clear precisely when the first statutes expressly granted limited liability to stockholders, though the common law doctrine appears to have been well established from an early date.

${ }^{9}$ See Liggett Co. v. Lee, 288 U.S. 517 (1933).

${ }^{10}$ See id.
} 
accomplish both of these ends undoubtedly confused matters among lawmakers and gave rise to many opportunities for messy compromises.

In any case, given the minimum capital requirements, it was necessary for an entrepreneur who sought to form a corporation for purposes of conducting business (usually called a promoter in the older cases) to specify in advance the number of shares to be sold and the price at which those shares would be sold. Practically speaking, investors would not likely invest unless they knew these facts. Moreover, this system had the effect of ensuring that all investors would be treated more or less equally at least in the initial round of share sales. (And various other rules made it difficult to sell additional shares later anyway.) It seems fairly clear that the idea of par value came from this practical necessity. Although it is now obvious that setting par at the price at which one expects to sell shares can be unduly confining if it later becomes necessary to sell more shares, it is understandable that in the early days promoters gave little thought to the possible need for a subsequent issue of shares because of the relatively low limits that many states placed on maximum capital. ${ }^{11}$

This system also required a special rule relating to contracts to sell shares. It is the corporation that must issue shares. But the corporation may not exist at the time an investor agrees to invest. In such circumstances, there is no counterparty to the investor's agreement to invest. Therefore, there is no enforceable contract. Thus, the states enacted statutes that made subscription agreements enforceable by the corporation to be formed for some specified period of time. These statutes remain on the books in most states, but they are rarely used today, because it is very easy to form a corporation, and because a share subscription constitutes an offering of securities under the 1933 Act, which therefore must be registered. ${ }^{12}$

This system also had the effect of protecting creditors or at least affording them a possible remedy. If the corporation became insolvent, creditors could pursue subscribers who had not yet paid for their shares. In addition, if a promoter failed to garner sufficient

\footnotetext{
${ }^{11}$ This may also be due to the fact that it was possible to make subsequent assessments on shares. Today, shares are invariably fully paid and non-assessable.

${ }^{12}$ These statutes also contain provisions relating to the manner of making calls on subscribers that are designed to assure that all are treated equally in having their subscription agreements enforced.
} 
subscriptions or payments, but began to do business in the name of the corporation anyway, the promoter could be held personally liable for the debts of the business. ${ }^{13}$

In addition to rules relating to the minimum amount of capital that must be paid in before commencing business, corporation law limited the nature of the capital that could be contributed. It seems fairly obvious that one way to circumvent the requirement of payment for shares pursuant to a subscription would be to pay with a promissory note, in effect substituting one obligation for another. Some states appear to have required that contributions be in cash, though most states ultimately adopted statutes that prohibited payment in the form of a promise to pay or a promise of future services.

The par value system was passable for purposes of assuring equal treatment among new stockholders, but it failed to protect new stockholders from promoters who might have sold themselves stock on the cheap before selling stock to the general public. In such a case, a new stockholder has no standing to sue, because the corporation is presumed to have assented to the terms on which it sold stock and the new stockholder is presumed to have paid a fair price for his stock. ${ }^{14}$

Undoubtedly part of the problem lay in the fact that promoters had begun seeking capital from strangers who had little access to information about the businesses being promoted. As a result of this

\footnotetext{
${ }^{13}$ This system was particularly strong in southern states such as Georgia and Virginia and gave rise to litigation into the late 1930s. It is worth noting that the word promoter is more or less a term of art in the older case law, referring to a person who seeks to form a corporation and find investors. Although the term remains in some use, it is so easy to incorporate today that it is foolish not to form a corporation before taking any other steps in connection with promoting the business. (If one has already formed a corporation before taking any other steps to sell stock or enter into other contracts for the benefit of the business, then the corporation itself can enter into contracts including contracts with investors and avoid the issue of personal liability at least in the absence of fraud.) Today, cases involving promoters are typically viewed as examples of stupid mistakes made by business people without the most basic knowledge of corporation law. In fairness, it may often have been rather difficult to convince potential investors to subscribe or thereafter pay without first lining up various inputs for the business. In other words, it seems likely that many promoters faced a serious chicken and egg problem in setting up a business. Many of the older cases involving promoters may have come up during the period following a successful subscription but before investors had in fact paid in their capital contributions. Thus, it is hardly fair to dismiss the older cases as simple examples of promoters who did not know enough to complete formation of the corporation before commencing business.
}

${ }^{14}$ See Old Dominion Copper \& Smelting Co. v. Lewisohn, 210 U.S. 206 (1907). But see Old Dominion Copper \& Smelting Co. v. Bigelow, 203 Mass. 159 (1909). 
problem the states began to pass so-called blue sky laws. The first such law was enacted by Kansas in $1911 .{ }^{15}$ Within a short period of time virtually every state had some such law. In most cases, these laws empowered the state securities commissioner to review the merits of an offering, and to prohibit the sale of investments that were found not to be fair, just, and equitable to investors. Hence, the system came to be known as merit regulation. State blue sky laws had numerous problems. For one, it was difficult for a securities commissioner to pursue unscrupulous promoters across state lines.

Accordingly, Congress enacted the Securities Act of $1933 .{ }^{16}$ Unlike most state blue sky laws at the time, the 1933 Act mandates only disclosure. ${ }^{17}$ It establishes a system under which an offeror must file a registration statement with the Securities \& Exchange Commission, disclosing all material facts about an offering, including any prior issuance of stock to promoters. In addition, a prospectus (which is essentially a copy of the registration statement without the exhibits) must be delivered to every investor. Finally, the 1933 Act provides straightforward remedies for investors if the issuer misrepresents or fails to disclose any material fact about the offering. In effect, the 1933 Act solved the stockholder standing problem by giving the stockholder a more or less absolute right to get back his money. It also swept away most of the rationale for the par value system (as far as stockholders are concerned) in that it effectively required that public offerings be conducted by the sale of a fixed amount of stock at a fixed price per share. ${ }^{18}$

Another well recognized problem with the par value system was that it could create difficulties in connection with subsequent offerings of stock. Suppose that a company set its par value at $\$ 100$ per share

\footnotetext{
${ }^{15}$ See Paul G. Mahoney, The Origins of the Blue-Sky Laws: A Test of Competing Hypotheses, 46 J. Law \& Econ. 229 (2003).

${ }^{16} 15$ USC 77 a et seq.

${ }^{17}$ The initial proposal to Congress was for a system of federal merit regulation. State blue sky law was essentially pre-empted by federal securities law by the passage of the National Securities Markets Improvement Act (NSMIA) in 1998.

${ }^{18}$ Despite the 1933 Act, blue sky laws remain in force in every state. Although many states follow the Uniform Securities Act, there are significant variations state to state. The NSMIA further limited the reach of state blue sky laws, preempting them in connection with any offering governed by federal law. Thus, they apply only to offerings wholly within a state, which are also exempt from federal law. On the other hand, many state blue sky laws govern a broad range of financial services that are not within the scope of federal securities law.
} 
and sells the entire initial offering at that price. Five years later, market prices generally have fallen by 30 percent, and the shares of the company are selling for $\$ 70$. Given that most companies tend to follow the market up and down, one would expect the stock to be trading at $\$ 70$ even if the business has performed as expected. The company wants to sell additional shares, but its charter requires that the shares be offered at $\$ 100$-- which no investor will pay. There was some authority to the effect that a corporation could sell shares at less than par under such circumstances, but it was arguably limited to situations in which the corporation would otherwise fail. ${ }^{19}$

The obvious solution to this problem is to amend the charter to reduce par value to $\$ 70$ or some lower number. But there appears to have been a strict rule against reducing capital. ${ }^{20}$ As a result of this problem, New York amended its corporation law in 1912 to permit the use of no par stock. ${ }^{21}$ Despite the name, no par stock is still very much part of the par value system. The general rule with no par stock is that the stock may be sold for any amount set by the board of directors, but the entire amount received for stock must be treated as stated capital. ${ }^{22}$

It is fairly clear that neither the ability to amend the charter to reduce par value nor the practice of issuing low par stock was widespread or even extant as of 1912 . But it is not surprising that after 1933 corporations began to issue stock with a low par value simply to plan for the possibility of further sales of stock in the future. After all, the 1933 Act effectively protected investors against overpayment and dilution far better than the par value system had done. Neither is it surprising that although the states could have eliminated the par value rules at this point -- if the only concern was equal treatment among stockholders -- they were probably reluctant to eliminate the par value requirement entirely because of the rights that creditors had come to enjoy. Nevertheless, those protections had become quite slim.

${ }^{19}$ See Handley v. Stutz, 139 U.S. 417 (1891).

${ }^{20}$ See, e.g., Charles T. Boone, MANUAL OF THE LAW APPLICABLE TO CORPORATIONS GENERALLY § 114 (1882). See also Bove v. Community Hotel Corp., 249 A.2d 89 (R.I. 1969) (noting that as late as the 1960s Rhode Island law did not permit amendment in connection with terms of outstanding preferred stock except by unanimous vote).

${ }^{21}$ See Vaughan v. State of New York, 272 N. Y. 102 (1936).

${ }^{22}$ The rule was later modified to permit the board of directors to designate some lesser amount as stated capital. See MBCA 21. 
The par value system had other another independent set of implications for dividends (distributions of property) to stockholders. ${ }^{23}$ In the traditional system, the corporation could make distributions to its own stockholders only to the extent that it had generated profits -funds in excess of its capital. To return capital would in effect violate the par value system by permitting stockholders to pay par formally at the outset and then to get a rebate of some of the money. Thus, the par value system required rules about distributions. To borrow a phrase from trust law, the most basic rule was in essence that a corporation could not invade capital to pay a dividend. Practically speaking this meant that the corporation could pay dividends only out of profits. But there were many variations on this basic theme, as I discuss further below.

One problem with a strict rule against invasion of corporate capital is that sometimes a corporation may raise more capital than it needs. Presumably, the corporation should be able to refund unneeded capital to its stockholders. Arguably it might even be required to do so. ${ }^{24}$ So a strict non-invasion rule might be too strict. In any event, the rules relating to distributions offered (some) creditor protection in addition to the rules relating to the issue of stock.

The point for present purposes is that there were two somewhat independent but related rationales for the par value system: regulation of stock issuance and regulation of distributions to stockholders. Taken together, they must have appeared to be good reasons not to do away with the par value system altogether despite the increasingly common practice of using low par stock. In effect, the idea may have been to permit corporations to specify some amount of minimum capital that would be raised and maintained, but it is unclear that by 1950 either stockholders or creditors placed much reliance on these rules.

\section{LEGAL CAPITAL IN CURRENT PRACTICE}

Legal capital rules vary widely from state to state, but there are essentially five models in common use. I classify these according to

\footnotetext{
${ }^{23}$ The MBCA uses the word distribution to refer to payments of cash or property to stockholders. The word dividend is used only in connection with distributions of stock (stock dividends and stock splits).

${ }^{24}$ See, e.g., Dodge v. Ford Motor Co., 170 N.W. 668 (1919) (requiring payment of dividend to the extent corporation had retained funds for which it had no use).
} 
the rules relating to ordinary distributions to stockholders. The 1950 Model Business Corporation Act (MBCA) follows an earned surplus rule. The 1984 Revised Model Business Corporation Act (RMBCA) follows a simple balance sheet rule. ${ }^{25}$ Both Delaware and New York follow simple surplus rules. California follows a percentage test. Finally, Massachusetts has no balance sheet rules at all. I discuss each of these schemes below.

\section{Model Business Corporation Act}

In the early 1940s, the Committee on Corporate Laws of the ABA Section of Business Law began work on the Model Business Corporation Act. There were several reasons for the development of the MBCA. There was a perception that the federal government was likely to call for a uniform federal incorporation law. There was also a perception that Delaware law was too management friendly and that there was a need for a statute that gave more weight to the interests of stockholders. And undoubtedly there was a need for more organized statute (with commentary) that might make some sense out of the various state statutes that had evolved in a somewhat random fashion. ${ }^{26}$

The 1950 Model Act was quite influential and came to be followed in whole or large part by as many as thirty-five states before it was revised in 1984. It continues to be followed in several states today. Nevertheless, it is important to recognize that the MBCA was developed and continues to revised and updated by a committee of the ABA. Although it has been widely followed by the states, it has no independent legal status. ${ }^{27}$ In any event, this model statute, which

\footnotetext{
${ }^{25}$ The Revised Model Business Corporation Act was officially renamed the Model Business Corporation Act in 1988, dropping the word revised from the name. Nevertheless, for clarity, I will here refer to the 1984 Act as the RMBCA in order emphasize the differences between the two acts.

${ }^{26}$ See Richard A. Booth, A Chronology of the Evolution of the Model Business Corporation Act, 56 Bus. Law. 63 (2000).
}

\footnotetext{
${ }^{27}$ It is important to note that the MBCA is a model act not a uniform act. Whereas a uniform act is intended to be more a less identical from state to state, a model act is intended more as a standard form from which to develop a statute that suits the particular needs of the jurisdiction. There was in fact a uniform business corporation act under development in the 1930s and 1940s, which confusingly also went by the name Model Business Corporation Act. The name was subsequently changed to the Uniform Business Corporation Act. It was adopted by a handful of states in the 1950s, but never achieved the popularity of the MBCA. It has apparently been withdrawn.
} 
came to be widely followed, gives a good snapshot how corporate lawyers thought at that time. The 1950 Model Act reflects what were seen as best practices at the time. ${ }^{28}$ Today, the 1950 Model Act may be seen as fairly simple statement of the traditional par value rules.

Under the 1950 Model Act, the articles of incorporation must specify a par value for shares and must specify the maximum number of shares that may be issued. ${ }^{29}$ There is no minimum par value for common shares. If the shares are to have special rights - such as preferred shares - those rights must be spelled out with specificity. ${ }^{30}$ The 1950 Model Act also permits no par shares. ${ }^{31}$

Shares with par value may be issued at any price determined by the board of directors but only if the price is at least equal to the par value of the shares. ${ }^{32}$ In other words, a stockholder who acquires newly issued shares from the corporation must pay at least par for those shares. Notwithstanding the express requirement that a stockholder pay at least par for shares, the 1950 Model Act makes it clear that the stockholder is obligated to pay the agreed consideration for the shares and that when the agreed consideration is paid the shares are deemed to be fully paid and non-assessable. ${ }^{33}$

The idea behind this provision is that is that the stockholder should be protected against a claim that the board of directors may have sold shares too cheaply. The provision does not purport to protect the board of directors against a possible claim that it sold shares too cheaply. It is also worth noting that the provision that deems shares to be fully paid and non-assessable is significant in that the law of some states (for example, California) presumed that shares were assessable until well into the 1900 s. ${ }^{34}$

\footnotetext{
${ }^{28}$ The original MBCA was patterned on the Illinois Business Corporation Act.

${ }^{29}$ MBCA 15, 54.

${ }^{30}$ MBCA 15. See, e.g., Southern Pacific Co. v. Bogert, 250 U.S. 483 (1919).

${ }^{31}$ MBCA 15, 54.

${ }^{32}$ MBCA 18.

${ }^{33}$ MBCA 19.

${ }^{34}$ See Martin v. Palmer Union Oil Co., 184 Cal. 386, 193 P. 950, 1920 Cal. LEXIS 334.
} 
The 1950 Model Act provides that a stockholder or subscriber is under no obligation to the corporation or its creditors other than to pay the agreed price for shares to the corporation. ${ }^{35}$ This provision is ambiguous on several levels and probably intentionally so. It is clear that the obligation to pay runs to the corporation, but the provision does not necessarily preclude action by a creditor on behalf of the corporation. And indeed some states permit creditors to maintain a derivative action. It does not appear that the creditors may sue and recover directly. Practically speaking, creditors are likely to sue only if the corporation is insolvent. If so, the corporation will likely be in the hands of a receiver or bankruptcy trustee who can sue in the name of the corporation anyway. Thus, it does not appear that it makes much difference whether the creditors have standing to enforce the pay-in obligation. The 1950 Model Act makes no distinction between the portion of the payment equal to par value and any excess amount that a stockholder may have agreed to pay. Some state statutes suggest such a distinction and even suggest that creditors may sue directly for such amounts but not for amounts in excess of par value. ${ }^{36}$

Under the MBCA, shares that have been validly issued by a corporation and then reacquired by it are classified as treasury shares. ${ }^{37}$ These shares are treated as if they are still outstanding in the hands of a stockholder (except for the fact that the shares cannot be voted). None of the legal capital rules relating to the pay-in obligations of stockholders apply in connection with the subsequent (re)disposition of treasury shares. Treasury shares may be sold for any amount or form of consideration (on the theory that a stockholder could resell shares for any amount or form of consideration).

The 1950 Model Act includes the usual restrictions on the form of payment for shares. Promissory notes and future services are

\footnotetext{
${ }^{35}$ MBCA 25.

${ }^{36}$ It may matter, however, if the court interprets fiduciary duty as a duty to serve stockholder interests exclusively rather than as one running to the corporation as an entity. For example, a court might rule that the obligation to pay in par value is a statutory obligation that runs to the entity, while the obligation to get top dollar for each share is an obligation that runs only to the existing stockholders. If so, the court might conclude that a bankruptcy trustee is precluded from pursuing claims for amounts in excess of par value. This distinction has been glossed over until recently. Bankruptcy trustees have been largely free to pursue any claim that the stockholders might have had. See, e.g., Costello v. Fazio, 256 F.2d 903 (9th Cir. 1958).

${ }^{37}$ See RMBCA 6.31, Official Comment; Manning \& Hanks at $84-86$.
} 
prohibited as payment, but payment may be in the form of tangible or intangible property. ${ }^{38}$

The 1950 Model Act included a provision requiring minimum paid in capital of $\$ 1000$ before a corporation might lawfully commence doing business. That provision was eliminated in $1969 .{ }^{39}$ Thus, the Model Act has never included a significant minimum pay in requirement in addition to the minimal protections afforded by the par value rules.

The 1950 Model Act includes detailed definitions and rules relating to the legal capital accounts that must be set up and maintained by a corporation in the equity portion of the balance sheet. These include stated capital, capital surplus, and earned surplus. In essence, stated capital is the amount paid for stock that equals the par value of the stock, capital surplus is any additional amount that is paid in (or otherwise generated on the balance sheet), and earned surplus is surplus that arises from profitable operations. That is, earned surplus is essentially the same thing as retained earnings under GAAP. ${ }^{40}$ The 1950 Model Act does not require that the corporation adhere to any particular accounting method in making the determination that a dividend or distribution may be paid. ${ }^{41}$

The dividend rules under the 1950 Model Act are quite complex and difficult to summarize. All dividends and distributions are subject to a solvency requirement. That is, the dividend may not render the corporation unable to pay its bills as they become due. ${ }^{42}$

There are in essence four separate sets of rules applying to distributions under the 1950 Model Act.

\section{Ordinary Dividends}

\footnotetext{
${ }^{38}$ MBCA 19.

${ }^{39}$ See Richard A. Booth, A Chronology of the Evolution of the MBCA, 56 Bus. Law. 63 (2000).

${ }^{40}$ MBCA 21.

${ }^{41}$ Thus, one might say that the corporation is permitted under the MBCA to keep its books relating to legal capital in any reasonable way. It is also worth noting that under US law, there is yet another separate accounting system imposed for federal income tax purposes. Thus, it is quite possible for a corporation to have three sets of books.

${ }^{42}$ MBCA 6, 45, 46, 66.
} 
Ordinary dividends may be paid out of earned surplus (retained earnings) only. ${ }^{43}$ There is an optional provision that permits distribution also out of current earnings (a nimble dividend), which may be important for a corporation that has built up losses over several years but that has become profitable more recently. The statute also permits dividends to the extent of depletion or amortization for wasting assets corporations.

\section{Return of Capital}

Dividends may be paid out of capital surplus if the articles of incorporation permit it or if the distribution is approved by stockholder vote. ${ }^{44}$ No such distribution may be made if it would reduce remaining net assets below aggregate outstanding liquidation preferences.

\section{Repurchases}

A corporation may repurchase its own shares to the extent of earned surplus (or capital surplus if the articles of incorporation permit or the stockholders approve) ${ }^{45}$ In other words, the rules here are essentially the same as those that apply to ordinary dividends.

\section{Redemptions}

A corporation may redeem redeemable shares as long as net assets are not reduced below the liquidation preferences attributable to shares with equal or prior rights. ${ }^{46}$ This is the most liberal standard in the MBCA. Theoretically, the corporation could even invade stated capital to redeem redeemable shares.

Practically speaking, the above rules boil down to a rule that a corporation may not invade stated capital to make distributions to stockholders. Capital surplus is freely available if the articles of incorporation so state or if the stockholders approve. Thus, these rules afford little protection to creditors. Moreover, stated capital may be

\footnotetext{
${ }^{43}$ MBCA 45.

${ }^{44}$ MBCA 46.

${ }^{45}$ MBCA 6.

${ }^{46}$ MBCA 66.
} 
reduced by an ordinary amendment to the articles of incorporation which can also be achieved by a simple stockholder vote. ${ }^{47}$

Despite the fact that the legal capital rules do little to protect creditors, the solvency test which overarches all of the various balance sheet tests, affords some genuine protection for creditors, although it is unclear that it adds any level of protection beyond that provided by state fraudulent conveyance and fraudulent transfer laws (which similarly are based on both equitable solvency and balance sheet tests). On the other hand, the intricate balance sheet rules may afford important protections among various classes of stockholders.

If a dividend is paid illegally, the directors who assented to it (that is, those who failed to register an express objection) are liable to the corporation for the illegal portion of the dividend, and stockholders who receive a dividend knowing that it is illegal are liable in contribution to the directors who are held liable. ${ }^{48}$

In addition to the foregoing, rules relating to distributions of cash and property, there are elaborate rules relating to the distribution by a corporation of its own shares. For the most part, these rules specify how stated capital should be augmented when stock is issued under a stock dividend or in connection with a merger or other fundamental change. ${ }^{49}$

\section{Revised Model Business Corporation Act}

The MBCA was thoroughly revised in 1984 (although many of the substantive changes had been effected by the 1980 amendments to the earlier version of the act). All references to par value (and shares without par value) were eliminated. ${ }^{50}$ This also had the effect of eliminating capital accounts. The RMBCA also eliminates rules relating to the form of payment that may be used for shares. The RMBCA retains the somewhat ambiguous rule that a purchaser of shares is not liable to the corporation or its creditors except for the amount agreed

\footnotetext{
${ }^{47}$ MBCA 58.

${ }^{48}$ MBCA 48.

${ }^{49}$ MBCA 18, 21, 45, 70.

50 The RMBCA does state, however, that a corporation may provide in its charter that its stock shall have a specified par value. RMBCA 2.02. It is not clear what effect this would have. It could imply that traditional rules apply.
} 
to be paid for shares. ${ }^{51}$ In addition, the RMBCA eliminates all reference to treasury shares. Shares reacquired by the corporation become authorized but unissued shares. ${ }^{52}$

The RMBCA adopts a single unified test for all distributions. ${ }^{53}$ There is no special rule relating to repurchases or the redemption of redeemable shares under the RMBCA. As under the earlier act, this is a two part test consisting of a balance sheet and solvency test. As under the earlier act, the solvency test simply requires that the corporation remain able to pay its bills as they become due. The balance sheet test is greatly simplified (due in large part to the elimination of the various capital accounts). In essence, the test is simply that assets must be at least equal to liabilities after giving effect to the distribution. ${ }^{54}$ The RMBCA retains and extends the requirement that liquidation preferences (if any) be treated as roughly equivalent to stated capital. In other words, a corporation may not make a distribution to common shares if the distribution would decrease assets to an amount less than liabilities plus liquidation preferences on preferred shares. This rule was limited to dividends out of capital surplus under the 1950 Model Act but is extended to all distributions under the 1984 Act. But the RMBCA permits waiver of this rule in the articles of incorporation.

The RMBCA specifies that repurchase debt - a promissory note given by the corporation in payment to a stockholder selling his shares back to the corporation - is on par with (ranks equal to) third party debt if the corporation is able to satisfy the balance sheet test as to the full amount of debt at the time of repurchase. The case law has been in conflict on this point. In some cases, stockholders who have resold their shares to the corporation in good faith have seen the notes they received subordinated to obligations to third parties because of vague notions that a selling stockholder should rank after third party creditors. The approach taken by the RMBCA is essentially that if the corporation could have distributed the cash up front, the debt should be treated as equal to any third party creditor claim, on the theory that the selling stockholder could have lent the money back to the corporation.

\footnotetext{
${ }^{51}$ RMBCA 6.22.

${ }^{52}$ RMBCA 6.31.

${ }^{53}$ RMBCA 6.40.

${ }^{54}$ RMBCA 6.40.
} 
If the corporation is unable to satisfy the balance sheet test as to the entire amount of repurchase debt at the time of repurchase, the RMBCA also permits repurchase using debt with a payment contingent on satisfying the balance sheet test as each payment comes due. The RMBCA makes it clear that such a debt does not itself count as debt for purposes of the balance sheet test. ${ }^{55}$ Subsequent amendments have also made it clear that interest on contingent debt would be treated as a distribution (rather than as true interest) and must meet statutory tests. ${ }^{56}$

These provisions relating to stockholder debt may well be among the most important innovations contained in the RMBCA. Prior to the promulgation of the 1984 Act, the status of such debt was often unclear. Thus, it is not entirely fair to say that these provisions necessarily favor stockholders at the expense of creditors. Rather, they simply clarify the situation and presumably facilitate the ability of stockholders and creditors alike to negotiate protections more effectively. ${ }^{57}$

The RMBCA eliminates financial tests for stock dividends and stock splits. It treats these distributions as new issues of stock subject only to limitations on the distribution of shares of one class to holders of another class. ${ }^{58}$

The 1984 Model Act retains the rule that the board of directors may use any reasonable method to determine assets and liabilities and makes it clear that this determination may be based on a fair valuation or other method that is reasonable under the circumstances.

\section{Delaware General Corporation Law}

Delaware is the most important source of state corporation law in the United States at least for publicly traded corporations. About half of all publicly traded corporations are incorporated there. As a result, the Delaware General Corporation Law (DGCL) applies to the

\footnotetext{
${ }^{55}$ Thus here the act effectively dictates accounting treatment that may differ from GAAP.

${ }^{56}$ Such interest payments are probably nevertheless deductible for federal income tax purposes. See Mountain State Steel Foundries, Inc. v. Commissioner, 284 F.2d 737 (4th Cir. 1960).

${ }^{57}$ These provisions also apply to repurchase of shares in lieu of dissolution under MBCA 14.34. There was no comparable provision under the 1950 Model Act.

${ }^{58}$ RMBCA 6.23.
} 
internal affairs of these corporations. Accordingly, most of the important judicial decisions relating to corporation law come from the Delaware courts. Although the courts of other states, as well as federal courts, may render decisions governed by Delaware law, the Delaware Court of Chancery is more or less dedicated to disputes involving corporation law - together with the law of other forms of business organization. As a result, this court is quite efficient with regard to such disputes, and litigants tend to prefer to litigate there, which also has the effect of concentrating business disputes in that forum.

Delaware continues to follow traditional legal capital rules, but with several important twists. A Delaware corporation must specify a par value for its shares (or that the shares are without par value). Shares may not be issued by the corporation for any amount less than par value. Limitations on the form of payment for shares are limited to the amount paid to cover par value. In other words, future services and promissory notes may be used to pay for any amount over and above par value that is paid for shares.

Although most observers had assumed that treasury shares could be sold (reissued) for any amount and for any form of consideration, a recent decision suggests that treasury shares are subject to the same restrictions on payment of at least par value as are newly issued shares. ${ }^{59}$

A Delaware corporation may pay dividends (and repurchase shares) to the extent of surplus or to the extent of net profits from the current or preceding year. ${ }^{60}$ There is no explicit solvency test in the DGCL. The term surplus is defined as the amount by which net assets exceed capital. ${ }^{61}$ (Presumably, the term net assets is the amount by which assets exceed liabilities, and the term capital refers to stated capital, that is, aggregate par value of shares outstanding. Thus, Delaware law permits a corporation to pay dividends to the extent that assets exceed liabilities plus stated capital.) The courts frequently refer to this test as an impairment of capital test. In other words, Delaware law makes no distinctions among sources of surplus. Thus, under the DGCL a corporation may use additional paid in capital (APIC) to pay a

\footnotetext{
${ }^{59}$ See Byrne v. Lord, 1996 WL 361503 (Del Ch. 1996). See also Public Investment Ltd. v. Bandeirante Corp., 740 F.2d 1222 (D.C. Cir. 1984) (construing DC law derived from the 1950 MBCA).

${ }^{60}$ DGCL 160, 170.

${ }^{61}$ DGCL 154.
} 
dividend or repurchase shares. In effect, the DGCL combines a simple surplus test with a very liberal earned surplus test and permits a corporation to use either test.

A dividend may not be paid out of net profits (nimble dividend) if capital representing preferred shares is impaired. On the other hand, it is generally agreed that under Delaware law a liquidation preference does not constitute capital. ${ }^{62}$

There is a special rule for corporations engaged primarily in the business of exploiting so-called wasting assets such as natural resources, patents, or copyrights, or the liquidation of specific assets. Such companies may in essence add accumulated depreciation, amortization, or depletion to net profits for purposes of calculating dividend paying capacity. The rationale for this decision is that such a company generates profits in effect by using up its assets. Potential profits are thus offset by a decrease in assets such that the company may never show any retained earnings even though the business is quite successful. This exception is presumably limited to dividends based on net profits. ${ }^{63}$

Delaware law permits net assets to be calculated in any reasonable manner. There is no requirement that the corporation adhere to GAAP or any other specific accounting method. Thus, a corporation may revalue assets at current value or fair market value for purposes of calculating net assets even though GAAP requires historical cost. ${ }^{64}$ To be sure, any such revaluation must be undertaken in good faith and should thus include a consistent and comprehensive review of both assets and liabilities and not merely a selective write up of particular assets. It is also clear that the board of directors may rely on outside experts such as accountants.

The Delaware courts have taken a broad view of board discretion in this area. For example, in one recent case, Klang v. Smith's Food

\footnotetext{
${ }^{62}$ See David A Drexler, et al., Delaware Corporation Law \& Practice $§ 20.03(2)$ (2004).

${ }^{63}$ Arguably, all corporations should be able to ignore depreciation and similar decreases in assets in connection with authorizing distributions on the theory that all assets get used up over time.

${ }^{64}$ See Morris v. Standard Gas \& Electric Co., 63 A.2d 577 (Del. Ch. 1949), citing, Randall v. Bailey, 23 N.Y.S.2d 173, 184 (App. Div. 1940), aff'd, 288 N.Y. 280, 43 N.E.2d 43 (1942). See also Kohls v. Duthie, C.A. 17762 (Del. Ch. July 26, 2000) (failure of directors to revalue assets in order to repurchase large block of stock at advantageous terms may be breach of fiduciary duty); Mountain State Steel Foundries, Inc. v. Commissioner, 284 F.2d 737 (4th Cir. 1960).
} 
and Drug Centers Inc., the Delaware Supreme Court approved the calculation of net assets based on a valuation of discounted cash flow (DCF) less long term liabilities. ${ }^{65}$ As the court recognized, this test ignores the balance sheet altogether or rather permits the use of projected future earnings to construct an alternative balance sheet. In effect, Klang conflates the two separate tests based on net assets and net profits into one. It is quite contrary to the traditional rule. ${ }^{66}$

\section{New York Business Corporation Law}

The New York Business Corporation Law (NYBCL) was substantially revised in 1998, but despite trends to the contrary, New York law retains most of the traditional rules relating to legal capital. New York law continues to require that a par value be specified (with the usual no-par alternative). ${ }^{67}$ A stockholder who purchases shares from the corporation must pay at least par value. ${ }^{68} \mathrm{As}$ under Delaware law, promises of future services or future payment may not be used to satisfy this requirement, but such consideration is acceptable for any amount to be paid for shares in excess of par value. ${ }^{69}$ In contrast to Delaware law, the New York statute expressly provides that treasury shares may be sold for any amount or form of consideration. ${ }^{70}$

New York law specifies that consideration received for shares shall constitute stated capital to the extent of the par value of the shares issued. ${ }^{71}$ When no par shares are issued, the entire amount of the consideration received is deemed to be stated capital unless the board of directors specifies some lesser amount within 60 days. The statute requires, however, that some amount must be designated as stated capital, a requirement that is merely implied in many other traditional statutes. ${ }^{72}$ If the corporation issues no par preferred stock,

\footnotetext{
${ }^{65}$ Klang v. Smith's Food and Drug Centers Inc., 702 A.2d 150 (Del. 1997).

${ }^{66}$ See See v. Heppenheimer, 61 A. 843, (N.J. Equity 1905).

${ }^{67}$ NYBCL 501.

${ }^{68}$ NYBCL 504(c).

${ }^{69}$ NYBCL 504(h).

${ }^{70}$ NYBCL 504(e).

${ }^{71}$ NYBCL 506(a).

${ }^{72}$ NYBCL 506(b).
} 
the entire amount of consideration received for up to the amount of the liquidation preference for such stock must be deemed to be stated capital. ${ }^{73}$ In other words, only the amounts in excess of par value may be transferred to surplus.

Under New York law, dividends and distributions may be declared and paid only to the extent of surplus. ${ }^{74}$ As under Delaware law, a wasting assets corporation may invade stated capital to the extent of depletion or amortization but only if stated capital sufficient to cover liquidation preferences if any is maintained. ${ }^{75}$ There is no other general requirement that stated capital be maintained to the extent of liquidation preferences. Thus, if the corporation issues low par preferred stock (as opposed to no par preferred stock), the surplus attributable to such stock may apparently be paid out in dividends even on common stock. It may be that such limitations are typically left to negotiation.

\section{California Corporations Code}

The California Corporations Code (CCC) relating to legal capital was thoroughly revised in $1975 .^{76}$ The concept of par value was eliminated. A system of dividend regulation based on GAAP was imposed. There are essentially two alternative tests for dividends. Under the retained earnings test, a corporation may pay a dividend to the extent of retained earnings. Under the remaining assets test a corporation may pay a dividend to the extent that after the dividend remaining assets will equal at least 125 percent of liabilities and current assets at least equal current liabilities. ${ }^{77}$ If average earnings is less than average interest expense, then current assets must equal at least 125 percent of current liabilities. In comparing assets and liabilities certain intangible assets and liabilities are excluded. California law also imposes an equity insolvency test. ${ }^{78}$

\footnotetext{
${ }^{73}$ NYBCL 506(b).

${ }^{74}$ NYBCL 510(b).

${ }^{75}$ NYBCL 510(b).

${ }^{76}$ See Manning \& Hanks at 176.

${ }^{77}$ CCC 500 .

${ }^{78}$ CCC 501.
} 
California law expressly requires that assets be valued as they are for financial statement purposes under GAAP. ${ }^{79}$ In other words, the corporation must use historical cost rather than fair market value except to the extent that GAAP permits the use of fair market value.

Repurchase debt is treated as a liability for purposes of testing subsequent distributions except for distributions in payment of the repurchase debt itself. This is roughly equivalent to traditional accounting for treasury stock.

If a corporation has preferred stock outstanding, it may make a distribution on common stock only if (1) remaining assets are at least equal to liabilities plus liquidation preferences and (2) retained earnings are least equal to the proposed distribution plus any cumulative preferred dividends in arrears. These provisions may be waived. ${ }^{80}$

As under the RMBCA, the term distribution is used to refer both to ordinary dividends and to repurchases. But several types of repurchases are excluded from the definition of distribution, including court ordered rescission (presumably including rescission in lieu of dissolution in a closely held corporation), voluntary rescission where it is likely to be ordered, and repurchases under an employee stock ownership plan. The latter two exceptions are nonetheless subject to the equity solvency test. In contrast, RMBCA 14.34 specifically requires the application of the distribution tests under RMBCA 6.40 to any payment in lieu of dissolution.

Under California law a distribution by a subsidiary corporation to parent stockholders is also deemed to be a distribution by the parent. Thus, a corporation must use consolidated financial statements to the extent that GAAP so requires. In contrast, RMBCA 6.40 specifically permits the use of unconsolidated statements. ${ }^{81}$

\section{OTHER SOURCES OF CREDITOR PROTECTION}

As should be apparent from the foregoing discussion, legal capital rules in the United States afford little protection to creditors or,

\footnotetext{
${ }^{79} \operatorname{CCC} 500(\mathrm{c})$.

${ }^{80}$ CCC 502, 503.

${ }^{81}$ See RMBCA 6.40, Official Comment 4.
} 
for that matter, to stockholders. To be sure, stockholders are well protected by federal securities law in connection with the issuance of shares by the corporation. While many bondholders also enjoy the protections of federal securities law (because public offerings of bonds must be registered), corporation law contains almost nothing that is designed to protect the interests of creditors. Rather, creditors must rely primarily on negotiated contractual protections, fraudulent transfer law, and ultimately the bankruptcy courts to protect themselves from overreaching for the benefit of stockholders. The legal capital rules do a somewhat better job of protecting rights as among various classes of stockholders, though even here preferred stockholders must depend primarily on privately negotiated contract. Common stockholders seem to need relatively little protection because they typically control the board of directors and if anything are on the receiving end of most questionable transactions. ${ }^{82}$ Thus, few observers in the United States are at all unhappy with the demise of the par value system. Indeed, most would likely agree that the system created unnecessary legal work and amounted to little more than a trap for the unwary.

This in not to say, however, that creditors do not enjoy significant protections under United States law. Indeed, these protections exist on several levels.

First, corporation law itself affords significant protection by providing a remedy for the payment of illegal distributions to stockholders. To be sure, this remedy is ultimately based on the rules relating to when dividends may be paid, which is to say the legal capital rules. But in addition to the balance-sheet-based legal capital rules, every state imposes an equity insolvency test in connection with the payment of dividends. In other words, a corporation may not make a distribution when to do so would render the corporation unable to pay its bills as they become due. In most cases, these rules are found in the corporation law itself. In some states (such as Delaware) the rule is imposed by case law or is found in a separate fraudulent conveyance or fraudulent transfer statute. In short, the law is quite clear that a corporation may not make a distribution to its stockholders if to do so would result in the inability of the corporation to pay its creditors. In the event that a corporation does make an illegal

\footnotetext{
${ }^{82}$ To be sure, common stockholders may suffer when management or a controlling stockholder has engaged in overreaching by extracting some sort of benefit from the corporation in violation of the general rule requiring equal treatment within a class of stock, but these are not problems that the legal capital rules ever addressed effectively.
} 
distribution to its stockholders, the directors are jointly and severally liable to the corporation for the amount of the dividend in excess of the legal amount. The directors in turn have a remedy against stockholders who received the illegal dividend knowing that it was illegal. ${ }^{83}$ There are few reported cases involving actions against directors for illegal distributions. This may be due to a variety of factors. For one, it may be that the legal capital rules make it too easy to pay dividends or that the courts have found it difficult to apply the equity solvency test. It may also be that other remedies are simpler or more familiar to litigators.

Second, in addition to the rules relating to illegal dividends, every state has a statute prohibiting fraudulent transfers. ${ }^{84}$ These rules are very similar to the rules relating to dividends. In most cases, they prohibit transfers of property for less than fair value if (1) the transfer renders the debtor (corporation) unable to pay its bills as they become due, or (2) the transfer occurs at a time when the debtor (corporation) is insolvent. ${ }^{85}$ These rules are considerably broader than those found in corporation law in several respects. For example, a creditor has standing to challenge a fraudulent transfer directly. There is no need to rely on a bankruptcy trustee or to commence a derivative action on behalf of the corporation. Moreover, a creditor may recover funds from the transferee.

The problem with fraudulent transfer statutes is that they give rise to the possibility that some creditors may recover (those who sue) while others do not. This problem could be avoided by treating such actions as derivative (for the benefit of the corporation) and permitting creditors to maintain such actions, but in most states only to stockholders have standing to maintain a derivative action. ${ }^{86}$ The same problem arises in connection with an action against the directors for an illegal dividend. Generally, corporation law provides that the corporation may recover for an illegal dividend. And needless to say, the stockholders as the recipients of the illegal distribution are unlikely

\footnotetext{
${ }^{83}$ See RMBCA 8.33.

${ }^{84}$ The Uniform Fraudulent Transfer Act (UFTA) has been adopted by most states, but a few continue to follow the older but very similar Uniform Fraudulent Conveyance Act (UFCA).

${ }^{85}$ See UFTA $\S 4$, UFTA § 5. These rules apply to individuals as well as corporations and other entities.

${ }^{86}$ See RMBCA 7.41. See also ALI, Principles of Corporate Governance (PCG) 7.02; Federal Rules of Civil Procedure 23.1 (FRCP).
} 
to sue. On the other hand, if the corporation is insolvent or in the vicinity of insolvency, it appears that a creditor may maintain a derivative action in some states, including Delaware. ${ }^{87}$

Practically speaking, it would be unusual for creditors to resort to a derivative action. The bankruptcy process will ordinarily preempt any such lawsuit. Once a corporation declares bankruptcy, all legal actions outside the bankruptcy proceeding are stayed and may proceed only with the approval of the court and only for the benefit of the bankrupt estate (the corporation). ${ }^{88}$ In most cases, a corporation that is on the verge of insolvency will voluntarily declare bankruptcy in order to obtain protection from actions by creditors.

It is possible for creditors to force a corporation into bankruptcy involuntarily, but it is rare. ${ }^{89}$ It is usually in the interest of the debtor corporation to control the process, because in most cases incumbent management will continue to run the company during the course of the bankruptcy as a debtor-in-possession (DIP). There is no requirement that a corporation be bankrupt or insolvent in order to file a bankruptcy petition. Thus, a corporation is free to declare bankruptcy whenever it wants to do so. And there have been notable cases in which solvent companies facing substantial contingent liabilities have sought bankruptcy protection to deal with such claims in a more orderly fashion. By the same token, a corporation is never required as a matter of law to file for bankruptcy protection. But practically speaking a corporation that is threatened with an involuntary proceeding will almost always file voluntarily first.

The bankruptcy court may appoint a trustee in either a voluntary or involuntary case if a party so moves, but a trustee is likely to be appointed only upon a showing of fraud, dishonesty, mismanagement, or incompetence. ${ }^{90}$ Still, in most cases in which it appears that the corporation has paid an illegal dividend, it is likely that a trustee will be appointed. And if a trustee is appointed, the trustee may maintain an action on behalf of the corporation to recover it. In such a case

\footnotetext{
${ }^{87}$ See Production Resources Group, L.L.C. V. NCT Group, Inc., 863 A.2d 772, 2004 Del. Ch. LEXIS 174.

${ }^{88}$ Bankruptcy Code $\S 362$.

${ }^{89}$ Bankruptcy Code $\S 303$. In most cases, three or more creditors must join in the petition.

${ }^{90}$ Bankruptcy Code $§ 1104$.
} 
there is no need for a derivative action. The action by the trustee amounts to the same thing.

Indeed, there have been numerous cases in recent years in which a bankruptcy trustee has sought to recover illegal distributions from directors, recipient stockholders, and the agents through which the distributions were paid. ${ }^{91}$ Most of these cases have been unsuccessful because bankruptcy law precludes the recovery of settlement payments in connection with transactions in securities and commodities. ${ }^{92}$ Specifically, this provision exempts payments made through the payment and settlement system relating to transactions in securities and commodities. (The rationale is that unwinding such payments could cause massive disruptions in the financial system that would undermine many subsequent transactions involving the cash from the original transaction.) In practice, this rule is not likely to apply except to publicly traded corporations, because only such corporations have shares that clear through the clearance and settlement system.

In summary, the rules relating to illegal distributions and fraudulent transfers are usually enforced within a bankruptcy proceeding when they are enforced. Such claims are assets of the bankrupt corporation and must be marshaled as other assets. These claims are usually litigated by the trustee as a separate case in a state or federal court of general jurisdiction rather than in the bankruptcy court. It is also possible for a variety of remedies contained within the Bankruptcy Code itself to come into play. For example, the Bankruptcy Code contains its own parallel fraudulent transfer provision. ${ }^{93}$ The Bankruptcy Code also contains additional remedies - such as the ability to avoid preferential transfers within the previous year - that may often obviate the need to resort to the law relating to illegal dividends or fraudulent transfers. ${ }^{94}$ Nevertheless, these laws are subject to the same limitations discussed above when the payment is made through the clearance and settlement system.

\footnotetext{
91 See Munford v. Valuation Research Corp. (In re Munford, Inc.), 98 F.3d 604 (11th Cir. 1996); Kaiser Steel Corp. v. Pearl Brewing Co. (In re Kaiser Steel Corp.), 952 F.2d 1230 (10th Cir. 1991); Zahn v. Yucaipa Capital Fund, 218 B.R. 656, 675 (D.R.I. 1998).

92 Bankruptcy Code $§ 546$.

${ }^{93}$ Bankruptcy Code $§ 548$.

${ }^{94}$ Bankruptcy Code $§ 547$.
} 
Yet another doctrine that may apply in many cases is equitable subordination. For example, where a stockholder has resold shares to the corporation in exchange for a note or has attempted to extract funds from the corporation by reducing a claim for salary or wages or other purported obligations to a judgment or promissory note, a bankruptcy court (or other court) may subordinate such claims to those of bona fide creditors on various grounds. ${ }^{95}$

It is also quite common for a corporation's creditors with unsatisfied claims to seek to pierce the corporate veil and to hold individual stockholders liable for the debts of the corporation notwithstanding the fact that corporation law expressly provides that stockholders shall have no personal liability for the obligations of the corporation. ${ }^{96}$ Although the law relating to piercing is confused, such cases almost always involve fraud or undercapitalization. ${ }^{97}$ It should be emphasized that piercing is different from equitable subordination in that in a successful piercing case, a defendant stockholder (or sometimes a director or officer) is held liable to the plaintiff creditor for the debts of the corporation personally. In a subordination claim, a stockholder-creditor (or other creditor) is simply made to wait to be paid until after other creditors have been paid. There are no reported cases of piercing in which the stockholders of a publicly held corporation have been held liable personally for the debts of the corporation. ${ }^{98}$ But there have been numerous cases in which creditors

\footnotetext{
95 See Pepper v. Litton, 308 U.S. 295 (1939); Taylor v. Standard Gas Co., 306 U.S. 307 (1939); In re Multiponics, Inc., 622 F.2d 709 (5th Cir. 1980); Costello v. Fazio, 256 F.2d 903 (9th Cir. 1958). The courts may also subordinate the claims of otherwise legitimate creditors who have attempted to gain priority over other creditors. For example, where a bank lends funds to a corporation in order to permit the corporation to buy back its own shares, knowing that the corporation may be rendered insolvent as a result and the lender has taken a security interest in connection with the loan, the security interest may be nullified and the claim in effect subordinated to those of other lenders.

${ }^{96}$ My own search of the Lexis database, indicates that there were more than 400 such reported cases in 2004 alone.

${ }^{97}$ See DeWitt Truck Brokers, Inc. v. W. Ray Flemming Fruit Co., 540 F.2d 681 (4th Cir. 1976). See generally Robert B. Thompson, Piercing the Veil Within Corporate Groups: Corporate Shareholders as Mere Investors, 13 Conn. J. Int'I L. 379 (1999). See also Richard A. Booth, Limited Liability and the Efficient Allocation of Resources, 89 Nw. U. L. Rev. 140, 147 (1994).

${ }^{98}$ Some scholars have proposed that limited liability should be abolished and that stockholders of even publicly traded corporations should be personally liable for the excess debts of the corporations in which they invest.
} 
of publicly held corporations have been threatened credibly with having their claims subordinated. ${ }^{99}$

An emerging doctrine that is closely related to piercing is the doctrine of successor liability. Most cases of successor liability involve either a purported sale of assets without assumption of liabilities or the continuation of an existing business under a new name. Many of these cases involve an attempt to escape products liability claims or environmental cleanup costs. Many also involve the sale of assets at a discount from fair market value, which tends to suggest that both seller and buyer were aware of contingent claims. ${ }^{100}$

In a closely held corporation, these doctrines (as well as fraudulent transfer law) effectively require a stockholder to insure that the corporation is adequately capitalized in light of the needs of the business. There is, however, very little law relating to how much capital is enough or even what constitutes capital. ${ }^{101}$ Nevertheless, there has been no suggestion in recent years that corporation law

\footnotetext{
${ }^{99}$ Subordination claims almost always arise in connection with a bankruptcy proceeding. In contrast, piercing claims almost always arise outside a bankruptcy proceeding.
}

${ }^{100}$ See Nissen Corp. v. Miller, 594 A.2d 564 (Md. 1991). A few states also retain laws relating to bulk sales that effectively require a company (no matter what form it takes) to notify creditors in connection with a sale of assets transaction. See UCC 6-101 et seq. It is worth noting that corporation law generally requires a stockholder vote in connection with a merger or sale of assets and that in the case of a publicly traded corporation, bondholders will thus have notice of any such transaction. RMBCA 11.04, 12.02. Most bond indentures require that bonds be paid off in the event of a sale of all or substantially all of the assets. See Sharon Steel Corp. v. Chase Manhattan Bank, N.A., 691 F.2d 1039 (2d Cir. 1982).

Many states have also enacted business combination statutes that preclude a corporation after a hostile takeover (a change of control not approved by the board of directors) from engaging in any merger or disposition of assets for a period of three years (but only if the takeover involved the acquisition of more than 15 percent but less than 85 percent of the shares of the target company). See DGCL 203. This provision is somewhat akin to EU rules against financial assistance in that it precludes a hostile bidder from using target assets to finance an acquisition. But it does not preclude financial assistance in either friendly transactions or transaction in which more than 85 percent of the stockholders tender their shares.

Finally, corporation law provides that creditors be notified in the event of dissolution and that adequate funds be set aside to satisfy their claims before any distribution may be made to the stockholders. Known creditors who receive individual notice must sue within 90 days if their claim is rejected. Unknown creditors must sue within three years of the publication of a general notice. If the corporation fails to give adequate notice, creditors may recover directly from the directors or the stockholders to the extent of any distribution. RMBCA 14.07 -- 14.09. Otherwise, such claims are presumably subject to the statute of limitation applicable to the claim.

101 One notable counter-example is Radaszewski v. Telecom Corp., 981 F.2d 305, 310 (8th Cir. 1992) (insurance may constitute capital). 
should reinstate any specific capital requirements. Thus, it appears that most corporation law scholars and practitioners see the admittedly vague requirements implicit in the common law as preferable to a bright-line standard that would undoubtedly be wrong for individual businesses much more often than it would be right.

Although the foregoing remedies serve to protect the interests of creditors, they generally do not require that a corporation take positive steps to protect the interests of creditors even when the corporation is on the verge of insolvency. For example, it is quite common in the context of a struggling business for a stockholder to lend additional capital to the business in an effort to save it but also in an effort to avoid putting more equity capital at risk. The courts have almost always treated such stockholder loans as bona fide creditor claims at least where the business appears to have been adequately capitalized in the first place. ${ }^{102}$

On the other hand, in recent years, the courts have begun to recognize that when a corporation is operating on the edge of insolvency, the board of directors assumes a fiduciary duty to protect the interests of creditors. ${ }^{103}$ It is not completely clear what the duty to creditors entails or when it is triggered. ${ }^{104}$ It might be argued that the duty is one primarily to preserve assets for the benefit of creditors. Or it might be argued that the board of directors remains free to pursue risky strategies that may entail losses for creditors, but should not undertake transactions for the benefit of the stockholders at the expense of creditors.

Thus, some courts have limited the duty to creditors. For example, one court, in applying Delaware law, has limited the duty to

102 See Arnold v. Phillips, 117 F.2d 497 (CA5 1941).

${ }^{103}$ See Credit Lyonnais Bank Nederland, N.V. v. Pathe Communications Corp., 1991 Del Ch. LEXIS 215; Official Comm. of Unsecured Creditors of Buckhead Am. Corp. v. Reliance Cap. Group (In re Buckhead Am. Corp.), 178 B.R. 956 (D. Del. 1994); Brandt v. Hicks, Muse \& Co. (In re Healthco Int'l Inc.), 208 B.R. 288 (D. Mass. 1997) (applying Delaware law).

${ }^{104}$ See Geyer v. Ingersoll Pubs. Co., 621 A.2d 784, 787-88 (Del. Ch. 1992) (in determining when duty attaches Delaware law is concerned with insolvency in fact rather than insolvency as defined by a statutory filing). The prevailing view appears to be that the duty may be triggered somewhat before the appointment of a receiver or trustee. See Pereira v. Cogan, 294 B.R. 449; 2003 U.S. Dist. LEXIS 7818 (SDNY 2003) (under Delaware law, directors and officers owe a fiduciary duty to the corporation's creditors at a point short of actual insolvency, that is, when the corporation is in the vicinity of insolvency). 
situations where directors of an insolvent corporation diverted corporate assets for the benefit of insiders or preferred creditors. ${ }^{105}$

\section{CONCLUSION}

Although United States legal capital rules once imposed significant requirements in connection with the amount of capital that must be contributed to and maintained in a corporation, those rules have lost virtually all of their significance and force for stockholders and creditors alike. Today, creditors must rely primarily on negotiated contractual protections, as augmented by a variety of statutory and common law protections. This system appears to work reasonably well, however, in that limited liability entities, which are entirely devoid of legal capital rules, have proliferated in recent years, and do not appear to be disfavored in the credit markets. The story is slightly different in connection with maintenance of capital, where solvency requirements appear to have real effect in regulating distributions to stockholders. Moreover, in practice such rules are equally applicable in the form of fraudulent transfer statutes to unincorporated entities.

\footnotetext{
${ }^{105}$ See In re Ben Franklin Retail Stores, 225 B.R. 646, 655-56 (Bankr. N.D. III. 1998) ("Creditors have a right to expect that directors will not divert, dissipate or unduly risk assets necessary to satisfy their claims. That is the appropriate scope of duty that exists only to protect the contractual and priority rights of creditors."). See also Bank of America v. Musselman, 222 F. Supp. 2d 792, 799-800 (E.D. Va. 2002) (applying Virginia law but referring to Delaware law) (individual creditor could not recover its own debt from officers and directors of an insolvent corporation absent selfdealing or other illegal conduct).
} 